\title{
MEMORY AND COMMEMORATION AS A SUBJECT OF ENQUIRY FOR AFRICAN CHRISTIANITY SCHOLARS
}

\section{Philippe Denis}

University of KwaZulu-Natal

denis@ukzn.ac.za

\section{ABSTRACT}

Little attention has been paid to the Christian churches in memory studies in southern Africa. Using new and existing research, the paper proposes a first approach to this new field of enquiry, with special reference to southern African Christianity. The churches embody their memories in liturgies, canonisations, monuments, commemorative events and name-giving practices. They utilise what French historian Pierre Nora calls lieux de mémoire (sites of memory). Commemorations reinforce identity, especially when identities are threatened by external forces, and they create social cohesion. By pointing at the past, they create meaning for the present. Churches, ecumenical bodies, religious movements and theological institutions articulate their memories in various ways. Memories can be lost and retrieved, contested or marginalised. When the context changes, in church as in society, memories which were oppositional at one point can become dominant or vice versa.

Keywords: Memory; commemorations; memorials; lieux de mémoire; saints; toponymy

\section{UNISA $\cong$}


Memory studies is a fast expanding field of research. It envisages the phenomenon of memory from an interdisciplinary perspective combining neurological, psychological, sociological, historical, literary and philosophical approaches. It also analyses how societies commemorate past events and past historical figures. ${ }^{1}$ This paper was prompted by a recent conference of the Church History Society of Southern Africa on memory and commemoration in the history of the Christian churches which was held in Potchefstroom, South Africa, on 13-15 August 2015. ${ }^{2}$

In essence all religions are concerned with memory. They mediate between the world of the humans and the supernatural through a founding event - usually associated with a founder who has a special connection to the supernatural - which is constantly remembered and relived in sacred texts and liturgies. Christianity is no exception: at the centre of the Christian religion is the salvific event of Christ's death and resurrection, which is re-enacted in the Eucharist and celebrated in confessions of faith. Major Christian figures such as the apostles, the great theologians, the founders of religious orders and the Protestant Reformers also become an object of memory in the churches attached to their names. Memory is a theological theme, as Johann Baptist Metz reminded us in his work on the 'dangerous memory of Jesus Christ. ${ }^{3}$ It is a topic with philosophical resonance as the Protestant philosopher Paul Ricoeur demonstrated in his book Memory, history, forgetting. ${ }^{4}$

French historian Pierre Nora's Lieux de mémoire (Realms of memory), ${ }^{5}$ a collection of essays which triggered, thirty years ago, an unprecedented wave of scholarly interest in memory and commemoration, devotes no less than six chapters - on themes such as the church tower, the cathedral, France first daughter of the church, Vézelay, Notre Dame de Paris and the Sacré Coeur of Montmartre - to religious themes. In subsequent years and particularly during the last decade, scholars of religion gradually started to pay attention to issues of memory, commemoration and memorialisation. The theory of memory provided new insights into well-studied

$1 \quad$ S. Radstone, 'Memory Studies: For and Against,' Memory Studies 1(1) (2008), 31-39; P. Denis and S. Marschall, 'Editorial - Memory Studies,' Alternation, 22(2) (2015), 1-7.

2 Some of the material used for this essay has been borrowed from papers read at the CHSSA conference in Potchefstroom. In some cases it has been reworked and expanded for the purpose of the project. Other data come from my prior research work and from other studies in the field. I express my gratitude to the participants in the CHSSA conference for their stimulating papers and their engagement with issues of memory and commemoration in southern African Christianity.

3 Johann Baptist Metz, Faith in History and Society: Toward a Practical Fundamental Theology (New York: Crossroads Publishing Company, 2007), 87-96.

4 Paul Ricoeur, Memory, History, Forgetting, translated from the French by Kathleen Blamey and David Pellauer, 2004.

5 Pierre Nora, ed., Les Lieux de mémoire, 3 Vol. (Paris: Gallimard, 1984-1992). English translation: Realms of Memory: The Construction of the French Past, 3 Vol. (New York: Columbia University Press, 1996-1998). 
topics such as the composition of the pseudo-Pauline letters, ${ }^{6}$ the cult of martyrs in medieval Europe ${ }^{7}$ or the role of John Wesley's figure in the establishment of Methodism. ${ }^{8}$ New themes of research in the history of Christianity have emerged, for example the memorialisation of Lord Byron, a man once deemed scandalous who ended up receiving a memorial floor stone at Westminster Abbey in 1969, ${ }^{9}$ the representation of religious themes in First World War memorials in England ${ }^{10}$ or the memorialisation of Christian victims of Soviet oppression in contemporary Russia. ${ }^{11}$

Whether in a dominant position as in pre-revolutionary Europe and colonial Africa, or restricted to a less influential role as in secular societies, churches and faithbased organisations have a place in a general history of memory and commemoration. This also concerns southern Africa. So far, memory studies scholars have paid little attention to religion in this region. ${ }^{12}$ This paper's ambition is to explore the idea a study of memory and commemoration in southern African Christianity, with special attention to questions of methodology. This is work in progress. Further research on memory practices in the Christian communities will hopefully follow.

\section{MEMORY AND COMMEMORATION}

Memory is the ability to encode, store and retrieve information. Different parts of the brain, all interconnected, are involved in the act of remembering. To each form of memory - habitual, short-term, long-term and traumatic - corresponds a type of

6 Philip Esler, "Remember my fetters": Memorialisation of Paul's imprisonment', in Petri Luomanen, Ilkka Pyysiäinen and Risto Uro (eds), Explaining Christian Origins and Early Judaism: Contributions from Cognitive and Social Science (Leiden: Brill, 2007), 231-259.

7 Jamie Wood, 'Persecution, Past and Present: Memorialising Martyrdom in Late Antique and Early Medieval Córdoba' Al-Masāq: Journal of the Medieval Mediterranean, 27/1 (2015), 41-60.

8 David J. Hart and David J. Jeremy (eds.), Brands Plucked from the Burning: Essays on Methodist Memorialisation and Remembering (Evesham: Wesley Historical Society, Evesham 2013).

9 Ascari Maurizio, "Not in a Christian Church": Westminster Abbey and the Memorialisation of Byron', The Byron Journal, 37(2) (2009), 41-50.

10 David Nash, Christian Ideals in British Culture: Stories of Belief in the Twentieth Century (London: Palgrave MacMillan, 2013), 101-117.

11 Kathy Rousselet, 'L'Église orthodoxe russe et la mémorialisation des répressions à la période soviétique : de la victime au héros', in François-Xavier Nérard et David El-Kenz, Commémorer les victimes en Europe: XVIe-XXIe siècles (Paris, Champ Vallon, 2011), 183-196 ; Karin Hyldal Christensen, 'Remembering the New Martyrs and Confessors of Russia', in Catharina Raudvere, Krzystof Stala, Trine Stauning Willert (eds), Rethinking the Space for Religion : New Actors in Central and Southeast Europe on Religion, Authenticity and Belonging (Lund: Nordic Academic Press, 2012), 193-234.

12 This is the case of Sabina Marschall's otherwise comprehensive study of commemorative monuments in post-apartheid South Africa. Apart from a casual reference to the Church of the Vow in Pietermaritzburg and to the Dutch Reformed Church's involvement in the upkeep of the Blood River monument, no mention is made of faith-based commemorations. See Sabine Marschall, Landscape of Memory. Commemorative monuments, memorials and public statuary in post-apartheid South Africa (Leiden: Brill, 2010), 279-281. 
neurological connection. This helps to understand the first characteristic of the act of memory. Memory is a dynamic process. When we remember, we select, organise, omit and sometimes invent aspects of our past experiences according to what we need, feel and believe in the present moment. The memories of the past are fluid. ${ }^{13}$ We remember the same events differently at different moments of our lives. In each new situation we change the manner in which we recall memories and structure them in our minds. This does not mean that we tell the truth the first time and a lie the second time. Rather it shows that memory is constantly at work, finding new connections in the brain to make sense of the events of life. ${ }^{14}$ 'The relation between autobiographical memory and a sense of self,' psychologists Minda Tessler and Katherine Nelson pointed out, "is a dynamic, interactive process in which self and memory organize, construct, and give meaning to each other in a way so intimate that we can truly say that we are what we remember and that our memories are ourselves. ${ }^{15}$

A commemoration, which is a ritual or a display destined to celebrate the memory of a person, a group or an event, operates in the same way. By referring to the past, it speaks to the present. Like individual memory, commemorations select, shape and orient past experiences for a purpose. Christian memories and Christian commemorations are no exception. Their role is to create meaning for a certain audience in a certain context. In a commemoration those who commemorate are as important as what is commemorated. ${ }^{16}$

Memory is the capacity of a person to remember. However - and this is the second characteristic of the memory process - we do not remember alone ${ }^{17}$ Consciously or unconsciously, what we remember is shaped by what we have heard, seen and read around us. We gain access to events reconstructed for us by others. This does not mean we merely duplicate the memory of others. All memories are placed on a continuum between individual and collective memory. However, influenced by the context, memory always remains an individual act.

The third aspect of memory is its contested character. Because memories are stored and retrieved for a given purpose, divergences of opinion frequently arise between those who remember. Remembering and sharing one's memories implies

13 Carolyn Hamilton, "Living by Fluidity": Oral Histories, Material Custodies and the Politics of Archiving', in Carolyn Hamilton, Verne Harris et al., Reconfiguring the Archive (Cape Town: David Philip, 2002), 209-228.

14 Luise White, 'Telling more: Lies, secrets, and history,' History and Theory, 39 (December 2000), 11-22.

15 Minda Tessler and Katherine Nelson, 'Making Memories: The Influence of Joint Encoding on Later Recall by Young Children,' Consciousness and Cognition,3 (1994), 321, quoted in Valerie Yow, Recording Oral History, A Guide for the Humanities and Social Sciences, 2nd ed. (Oxford: Altamira Press, 2005), 36.

16 Tzvetan Todorov, 'The uses and abuses of memory,' in Howard Machitello, ed., What Happens to History: The Renewal of Ethics in Contemporary Thought. New York: Routledge, 2001, 11-22.

17 Maurice Halbwachs, The Collective Memory (New-York: Harper and Row, 1950). 
positioning oneself on a terrain, be it impersonal, political, social or cultural, which, in one way or another, is disputed. ${ }^{18}$ It is in that sense that memory scholars speak of the 'politics of memory'. 19

The past is made of multiple meanings and contradictory events. Two dangers face commemorations, Tzvetan Todorov warned in a suggestive essay. ${ }^{20}$ The first is the desire to take control of the past and erase it at will, as totalitarian regimes try to do. The second, more subtle, occurs when people or groups sacralise the events of the past which fit their search for identity and cut off the memories which do not correspond to their view of history. Memory can be blocked, manipulated or abusively controlled. ${ }^{21}$ In situations of conflict the priority given by the dominant group to its memories leads to violence because the groups whose memories are excluded from commemoration feel threatened and resort to force to reinstate their view of the past.

The significance of commemorations can therefore be construed as political. ${ }^{22}$ Whether celebrated by a nation-state, a political party, a faith community or an interest group, they reinforce identity, especially in situations where identities are threatened by external forces, and they create social cohesion. This is particularly true of the Christian churches whose unity is constantly compromised by heterodox doctrines, deviant behaviours and conflicts of authority. A commemoration is a display of unity destined both for the membership of the church and for the outside world.

Yet, meanings other than political can be assigned to commemorations. Remembering and commemorating painful events also have psychological value. ${ }^{23}$ By naming the cause of grief, processing it through stories and monuments and celebrating it ritually, mourners find ways of dealing with grief and developing resilience. Graveyards, monuments to the dead, crosses on sites of car accidents and similar memorials have been used at all times by people in grief to deal with death and tragedy. Churches are often involved in these commemorative practices because of their ability to help mourners find a spiritual meaning in painful memories and articulate them in a positive manner.

To designate the socio-political spaces within which social actors advance claims for the recognition of their specific war memories and for whatever benefits

18 Philippe Denis and Philani Dlamini, 'Multiple layers of memory: The history of Mpophomeni told and retold,' Alternation, 22(2) (2015), 76.

19 Susannah Radstone and Bill Schwarz, eds, Memory: Histories, Theories, Debates (New York: Fordham University Press, 2010), 3. See also T.G. Ashplant, Graham Dawson and Michael Roper, eds, The Politics of War Memory and Commemoration (London and New York: Routledge, 2000).

20 Todorov, 'The uses and abuses of memory', 19.

21 Ricoeur, Memory, History, Forgetting, 68.

22 Ashplant et al., The Politics of War Memory and Commemoration, 7.

23 Ibid. For an example of this approach to war memorials, see Jay Winters, Sites of Memory, Sites of Mourning. The Great War in European Culture History (Cambridge: Cambridge University Press, 1995). 
they seek to derive from such recognition, Ashplant, Dawson and Roper speak of 'arenas of articulation'. They also speak of 'narratives of articulation', the shared formulations within which social actors couch their memories, and of 'agencies of articulation', the institutions through which social actors seek to promote and secure recognition for their war memories' ${ }^{24}$ These concepts are relevant to a study of memory and commemoration in the Christian churches. Our task in this paper is to review the arenas of articulation identified by agencies such as churches, religious orders, ecumenical bodies and Christian organisations to commemorate events and figures in the public space. Nora's phrase lieux de mémoire - literally 'sites of memory' or, as suggested by the English translator, 'realms of memory' is also helpful to describe the phenomenon of commemoration. Societies feel the need to commemorate when the continuity between past and present is interrupted. Commemorations are deliberate attempts to recall memories of the past which fade away. They are 'embodiments of memorial consciousness' ${ }^{25}$ Arenas, sites, bodies: all these terms refer to tangible manifestations of a collective memory. In southern Christianity, as elsewhere, the Christian churches never cease to embody their memories in monuments, anniversaries, hagiographies and name-giving practices to reassert old meanings or create new ones in situations of change and contestation.

\section{THE MAKING OF AFRICAN SAINTS}

Rituals commemorating a founding event constitute an essential part of most if not all religious systems. In Judaism the eight-day festival of Passover, celebrated from the 15th to 22nd of the Hebrew month of Nissan, commemorates the emancipation of the Israelites from slavery in ancient Egypt. Its Christian counterpart, the Eucharist, enacts the last meal Jesus shared with his disciples before he was arrested, tried and put to death. He is portrayed as having anticipated the rituals his disciples would conduct in memory of him after his death and the faith his followers would have in him after his passing away. 'By pouring this ointment on my body,' he said of the woman who poured a jar of expensive ointment on him in the house of Simon the leper on the eve of his death, 'she has prepared me for burial. Truly I tell you, wherever this good news is proclaimed in the whole world, what she has done will be told in remembrance of her (Mt 26:12-13).' The Christian practice of the Eucharist, attested from the earliest time, is based on Jesus' command to break the bread and bless the cup as he had done 'in remembrance of [him]' (Lk 22:19). This sacrament, one of the two accepted in all Christian churches, manifests the intention not only to remember Jesus but to experience his presence in the heart of all believers.

24 Ashplant et al., The Politics of War Memory and Commemoration, 16-17.

25 Pierre Nora, 'Between Memory and History: Les Lieux de Mémoire,' Representations, 26 (1989), 12. 
The churches also celebrate the memories of the saints. Informally at first, then following strictly laid-out canonical procedures, the Orthodox, Roman Catholic and Anglican churches publicly honour the memory of those among their members who are the object of a popular cult. Currently, the Roman Catholic Church recognises four degrees of sainthood: a candidate is declared 'Servant of God' when the bishop of the diocese where he died has started to investigate his possible sainthood, 'venerable' when the pope has recognised his heroic virtues, 'blessed' when the beatification process is completed and 'saint' when the canonisation process is completed.

As Pierre Deloos argued half a century ago, there is a sociology of canonisations. ${ }^{26}$ In theory the church declares saint its most worthy members. In practice, mundane factors such as the reigning pope's personality, the candidate's conformity with the doctrines deemed orthodox at the time, the zeal of the local bishop and the funds available to finance the canonisation process play a decisive role in the proceedings. In the second millennium males, priests and residents from Mediterranean countries such as France, Italy and Spain were the most likely to be canonised. ${ }^{27}$ Since the advent of Pope John-Paul II (1978-2005), the biggest producer of saints in Catholic history, the focus has changed but biases remain.

Take the case of sub-Saharan Africa. According to an anonymous but wellinformed list of saints, during the last 50 years, five African Christians or groups of Christians were declared saints, 21 blessed and four venerable. ${ }^{28}$ Of this number 14 were declared martyrs. The geography of the causes of beatification and canonisation in Africa is troubling: 18 out of the 30 saints or future saints concerned, nearly two-thirds of the total, are from East Africa with eight from Ethiopia alone. Only one - a Nigerian priest - is from West Africa and three - a priest, a sister and a layman - from central Africa, all from the Democratic Republic of Congo. Together Madagascar, Reunion and Mauritius count five saints or future saints. This is more than in the rest of southern Africa which boasts two blessed (Fr Joseph Gérard in Lesotho and Benedict Daswa in South Africa) and one venerable (Abbot Franz Pfanner in South Africa). For reasons which need to be explained, the chances of being beatified or canonised seem to be much higher in East Africa and in the islands of Madagascar, Reunion and Mauritius than in the rest of Africa. West Africa, where missionary life has been thriving since the sixteenth century, is virtually out of the game. Likewise priests (14), sisters (6) and brothers (2) have a better chance of being declared venerable, blessed or saint than lay people (6 individuals and a group of four men and two women). Men (22) have a distinct advantage over women (8) and missionaries from Europe (17) over Christians born in Africa (13).

26 Pierre Deloos, Sociologie et canonisations (The Hague: Martinus Nijhoff, 1969).

27 Ibid.

28 'List of saints from Africa', n.d. <https://en.wikipedia.org/wiki/List_of_saints_from_Africa > (accessed 13 September 2015). 


\section{LOST MEMORIES}

Protestants do not canonise saints but that does not prevent them from honouring, in all sorts of fashions, the memory of their more respectable members. Founders such as Martin Luther, John Calvin and John Wesley are the object of commemorative practices which border on hagiography at times. Particularly interesting from the point of view of a history of memory is the invention of heroes - drawing from oblivion models of Christian life and commemorating them through story-telling, monuments or academic events.

A good example is Maqhamusela Khanyile, a Norwegian Missionary Society convert executed on 9 March 1877 near Eshowe on King Cetshwayo's order. The unveiling of a commemorative cross by Sibusiso Ndebele, the premier of KwaZuluNatal, and Louis Sibiya, the president bishop of the Evangelical Lutheran Church in Southern Africa (ELCSA), on 11 March 2007, was the culmination of a process of memory retrieval in which a group of students from the Lutheran Theological College at Maphumulo, and their church history lecturer, Margarete Nürnberger, played a central role, as the latter recounted:

The search began when I was lecturer for Christian Education in what was then known as the Lutheran Theological College at Maphumulo. I had set my students an assignment to write a lesson outline for confirmation class on one of the fathers or mothers in the faith. Two students (who are now deans), Timothy Myeni and Lawrence Khuzwayo, came and asked for permission to write about Maqhamusela Khanyile. "Who is he?" I replied. "Don't you know about Maqhamusela?" came the astonished reply. "He was a Zulu martyr." I felt humbled: I had majored in Church History in my theological studies, been a Lutheran all my life and in relatively close contact with some mission work, but I had never even heard of this man. The students showed me Incwadi yeJubilee which tells the story of the first Zulu Christians in the Norwegian Lutheran mission work. There Maqhamusela's story is written up in one and a half pages with a picture of the first cross erected to remind us of God's grace in this man. That and a half page in du Plessis' Christian Missions in South Africa were the only sources of information that we had..$^{29}$

By erecting this memorial, the Lutheran Church - with the support of Sibusiso Ndebele, the son of a Lutheran pastor who worked in the archives of the Lutheran Theological College in the early 1970s while studying library sciences at the University of Zululand ${ }^{30}$ - sent a double message to the community of believers. The first, which is the most obvious, was that Christians were called to testify to their faith in Christ and that, in extreme cases, this could lead them to sacrifice their life. The

29 Margarete Nürnberger, 'Maqhamusela Khanyile's life and testimony', Natalia, 31 (2001), 34-52, here 34 .

30 Philippe Denis, 'Seminary networks and Black Consciousness in South Africa in the 1970s,' South African Historical Journal, 62 (2010), 174. 
second, liminal, was that, though imported by missionaries, the Christian religion was genuinely African. It was out of her own will that Maqhamusela suffered death to preserve her faith, not because missionaries had asked her to do so.

The case of Richard Moko, the first indigenous minister ordained by the Seventh Day Adventist Church in South Africa, ${ }^{31}$ is similar. In 1903, while he was exercising the ministry in the East London East Bank area, a group of Presbyterian ministers accused him of heresy for having encouraged young people to stay away from work on Saturdays and he was expelled from the township the following year. Not much is known of what happened to him afterwards. ${ }^{32}$ Without ignoring him completely, Seventh Day Adventist historians downplayed his importance. Apart from a brief mention in Arthur Whitefield Spalding's Origin and History of the Seventh Day Adventists, published posthumously in $1962,{ }^{33}$ the only texts dedicated to him were a notice in the Seventh Day Adventist Encyclopaedia in $1976^{34}$ and a short article in the October 1984 issue of the South African Union Lantern, the organ of the African Union Conference of the Seventh Day Adventists. ${ }^{35}$

Things changed after the fall of apartheid with more opportunities, in the Christian churches, to talk about the lives of black ministers. In less than 10 years no less than four writers celebrated Moko's memory and a memorial was erected in his honour in East London. The first author was an Adventist pastor by the name of Mzanempi Nhlapo who self-published in Durban a book on Moko entitled Tears of the Black Pulpit. In a blog posted in $2006,{ }^{36}$ he revealed that he had used among other sources, Keith Tangaard's Master's thesis on the origins of East London. ${ }^{37}$ In 2009 Tangaard, by then head of the history department on the East London campus of Rhodes University, posted the story of Moko's expulsion from East London in his

31 The idea of writing this section was triggered by Michael Sokupa, 'Celebrating the memory of Richard Moko: A Seventh-day Adventist heritage reflection.' Unpublished paper read at the Church History of Society of Southern Africa conference held in Potchefstroom, 13-15 August 2015.

32 Michael Sokupa, 'Law and religious freedom in South Africa: Challenges facing the Seventh-day Adventist Church', International Journal for Religious Freedom, 4 (2012), 111-113, reproduced in Nederduitse Gereformeerde Theologiese Tydskrif, 54 Supplement 4 (2013), 146-148.

33 Arthur Whitefield Spalding, History and Origins of the Seventh Day Adventists (Washington: Review and Herald Publishing Association, 1962), Vol. 4, 22.

34 Francis David Nichol, Seventh-day Adventist Encyclopedia, Vol. 10 (Washington D.C.: Review and Herald Publishing Association, 1976).

35 J.B. Cooks, 'Richard Moko: First Indigenous Minister of our Church in South Africa,' South African Union Lantern, 10 October 1986.

36 Mzanempi Clifford Nhalpo to Hlanga Mafani, 19 May 2010, in 'Hobbes' Place. An Exploration of Adventist History and Culture.' <https: hobbes.wordpress.com/2006/10/30/Richard-moko> (accessed 13 September 2015).

37 Keith Tankard, East London: The Creation and Development of a Frontier Community, (MA Thesis, Rhodes University, 1985). 
'Labyrinth of East London Lore' site. ${ }^{38}$ In 2011 a second book on Moko, this time by a journalist called Hlenga Mafani, saw the light under the title From Genesis to Germination: Richard Moko and other African pioneers of Seventh Day Adventism in the Cape. ${ }^{39}$ The same Mafani promoted the idea of a memorial in memory of Moko in East London. The fourth propagandist of Moko's memory is Michael Sokupa, a church historian based at the Heritage Centre of Helderberg College, the training centre of the Seventh Day Adventists. Unlike Nhlapo's and Mafani's books, aimed at a popular readership, his publications target an academic audience. ${ }^{40}$ Moko's story is exemplary. It shows how an agency of articulation of memory made of pastors, academics and publicists managed to challenge, within a short period of time, the dominant version of the Seventh-day Adventist Church' history, giving a new visibility to the story of the first indigenous minister of that church, a man almost completely forgotten.

\section{NEW TIMES, NEW MEMORIES}

For a long time Stellenbosch University was considered a stronghold of apartheid. In 1960 its theological professors were the first to repudiate the Cottesloe Consultation's resolutions which rejected race as a basis for exclusion from the churches. ${ }^{41}$ Beyers Naudé, who dissociated himself from the Dutch Reformed Church's position on this issue, was forced to resign his church post. Interestingly, it is the Faculty of Theology of the same university which preserves and celebrates Naude's memory today. The University of Stellenbosch awarded him an honorary doctorate in 2010 and, two years later, named after him a Centre for Public Theology which assists Christians in fulfilling their responsibility in the various public spheres of democratic South Africa. ${ }^{42}$ The Beyers Naudé Centre keeps the anti-apartheid theologian's archives, publishes some of his works and maintains his legacy alive through events and publications. The figure of Beyers Naudé which was vilified by Afrikaner theologians during the apartheid era is now exalted. By commemorating Naudé the Stellenbosch theologians send forth the message that they support the new political dispensation and renounce the once-sanctified theology of apartheid.

38 Keith Tangaard, 'The strange story of a black missionary. Sedition? Or plain bloody blindmindedness?' 14 October 2009. <http://www.eastlondon-labyrinth.com/townships/moko.jsp> (accessed 13 September 2015).

39 Hlenga Mafani, From Genesis to Germination: Richard Moko and other African pioneers of Seventh Day Adventism in the Cape (no place, 2011), 159.

40 See above footnotes 24 and 25.

41 Richard Elphick, The Equality of Believers: Protestant Missionaries and the Racial Politics of South Africa (Charlottesville: University of Virginia Press, 2012), 317; Robert Vosloo, 'The Dutch Reformed Church, Beyers Naudé and the ghost of Cottesloe,' Studia Historiae Ecclesiasticae 37(1) (2011), 1-17.

42 'The Beyers Naudé Centre of Public Theology' < http://academic.sun.ac.za/tsv/centres/ beyers naude_sentrum $>$ (accessed 14 September 2015). 
Similar developments took place at the Faculty of Theology of the University of Pretoria, which has historical links with the Dutch Reformed Church and the Netherdutch Reformed Church of Africa (Hervormde Kerk). By instituting, in February 2014, an 'A.S. Geyser Commemoration Lecture', it gave prominence to a Hervormde theologian who, like Naudé, was a member of the Christian Institute and suffered persecution from his church for opposing the racial policies of the South African government. Professor of New Testament studies at the University of Pretoria since 1945, Geyser was accused of heresy and insubordination because of his interpretation of Philippians 2:5-11. The charge of heresy was withdrawn by the synod of the Hervormed Church after recourse to the High Court, and he was reinstated. But the tension was such that he eventually resigned, in 1963, from his church. He subsequently took up a post of lecturer at Wits University, while remaining ostracised by the Afrikaner community for the rest of his life. When he died in 1985, only a handful of family members, fellow activists and academics mourned him. ${ }^{43}$ Geyser's role in the church's struggle against apartheid went unnoticed beyond the circle of his friends and students. By commemorating Geyser the theologians of the University of Pretoria, signify, like their colleagues from Stellenbosch, their commitment to the values of the new South Africa.

The context - in Naudé and Geyser's case the advent of democracy in South Africa - is a key element of all commemorations. But it can blur their meaning when the value systems of the groups which commemorate are challenged by rival forces. This is what happened in 1988 when the apartheid state, by then struggling for its survival, celebrated the tercentenary of the arrival of the Huguenots in South Africa. The Huguenot Festival was meant to celebrate, in the words of their patented historian, 'the nobility of spirit which [the Huguenots] brought with them to this country' ${ }^{44}$ Thrown into exile for having refused to submit to the commands of an impious leader, the Huguenots were represented as the symbol of Afrikaner resistance to British rule. The fact that the French refugees were forcibly assimilated into the Dutch-speaking population, driving their pastor, Pierre Simond, to leave the colony in protest, and that, according to the colony's authorities, they were all but pious, ${ }^{45}$ had been obliterated from the memories.

The idea of building a Huguenot memorial in Franschhoek was discussed for the first time in 1824. In later years a host of schools and church buildings were named

43 Andries van Aarde, Pieter de Villiers and Johan Buitendag, 'The forgotten struggle of Albert Geyser against racism and apartheid', HTS Teologiese Studies/Theological Studies 70(1) (2014), art. 2820, 10 pages; Wim Dreyer, 'Albert Geyser: Anti-Apartheid activist as portrayed by the media.' Unpublished paper read at the Church History of Society of Southern Africa conference held in Potchefstroom, 13-15 August 2015.

44 Pieter Coertzen, The Huguenots of South Africa, 1688-1988 (Cape Town: Tafelberg, 1988), 152.

45 Philippe Denis, 'The Cape Huguenots and Their Legacy in Apartheid South Africa', Bertrand Van Ruymbeke and Randy Sparks, eds, Memory and Identity: The Huguenots in France and the Atlantic Diaspora (Charlestown: University of South Carolina Press, 2003), 286-291. 
after the Huguenots: the Sticht Simondium in Franschhoek in 1851, the Huguenot College of Wellington in 1872, the Gedenkschool der Hugenoten in Dal Josaphat in 1882, the Huguenot-Gedenksaal in Cape Town in 1924 and the Huguenot Monument of Franschhoek in 1948, to mention the most important ones. In 1988, the year of the Huguenot Festival, the Huguenot Tunnel was inaugurated near Paarl. ${ }^{46}$ But it was also the time of the second state of emergency, when key civil liberties were suspended under the guise of a war against terrorism. For the members of the liberation movements, many of whom were in prison or in exile, the Huguenots looked more like oppressors than victims. The heroes were the freedom fighters. The 1988 Huguenot Festival is an example of a contested commemoration.

The case of Edinburgh 2010, the conference marking the hundredth anniversary of the World Missionary Conference of 1910 in Edinburgh in June 2010, calls for similar remarks. By creating a platform for missionary cooperation in non-European countries, the 1910 conference paved the way for ecumenism, anticipating the creation of the World Council of Churches in 1948. But it was not a representative conference. The missionary societies were allocated places strictly on the basis of their annual income with the result that of the 1215 official delegates 509 were British, 491 were North American, 169 originated from continental Europe and only 19 from the non-Western world, 18 of them from Asia. ${ }^{47}$ This mistake was corrected in 2010: the 300 delegates who attended the 2010 Edinburgh conference hailed from 65 countries, many of them from the south, and represented 115 denominations and 202 organisations.

But the impact of the 2010 conference can be measured in another way. Did it elicit any interest in the churches which benefited - positively through increased cooperation among missionary bodies - from the World Missionary Conference? Cogitator Mapala, who examined the participation of his church, the Church of Central Africa Presbyterian (CCAP) of Malawi, in the centenary celebration of the 1910 Edinburgh conference, ${ }^{48}$ came to the conclusion that, apart from the printing of tee shirts for the centenary celebration at Zomba Theological College, nothing was done in his church to commemorate the 1910 World Missionary Conference. The interviews he conducted with Malawian church leaders showed that they did not see any connection between Edinburgh 2010 and the life of their churches. Yet, in 2009, the CCAP found the resources to commemorate the 150th anniversary of David Livingstone's discovery of Lake Nyasa. This shows that commemorations do not have a fixed meaning. The message they produce reaches the audiences to which

46 Ibid, 301-302.

47 Brian Stanley, The World Missionary Conference Edinburgh 1910 (Grand Rapids: Eerdmans Publishing, 2009), 12. See also Klaus Fiedler, 'Edinburgh 1910, Africa 2010 and the Evangelicals,' Studia Historiae Ecclesiasticae 36(2) (2010), 53-71.

48 Cogitator Mapala, 'A critical reflection on the commemoration of the Edinburgh 1910 International Missionary Conference from a Malawian perspective.' Unpublished paper read at the Church History of Society of Southern Africa conference held in Potchefstroom, 13-15 August 2015. 
they are addressed - in this case the global ecumenical community and, locally, the Presbyterian Church of Malawi - in different ways.

\section{ALTERNATIVE MEMORIES}

For Bishop Antonius Markos, a Coptic prelate presiding over 35 churches in 10 African countries, the church of Jesus Christ has always been African. His church celebrates the memory of the evangelist Mark, also called John Mark (Act 12:25), who they believe was born in North Africa, wrote the gospel in Africa and evangelised Egypt. ${ }^{49}$ For them Alexandria was a Christian centre from the start. According to Bishop Markos, the 'blood bond' which relates Africa to the biblical tradition is even older. 'All the Africans,' he wrote, 'are inter-related through Ham [one of Noah's sons] who had four sons: Mizraim (father of the Egyptians), Cush (father of the Eritreans, the Ethiopians, the Kenyans and East Africans), Phut and Chanaan [who] fathered the rest of the African nations.' ${ }^{50}$

This little-known historical narrative embodies what can be described as an alternative memory. The dominant narrative is that Christianity spread from Palestine and Asia Minor into Greece, Rome and the rest of the Roman Empire. In the story of origins Africa came second. The catechetical school of Alexandria features prominently in church history books but it is said to date from the second century and not the first. By celebrating the memory of Mark - who is also called John Mark - the Coptic Church provides an alternative view of history, based on oral tradition, which gives Libya and Egypt the status of founder churches.

The feast of Easter, which Christians celebrate every year, commemorates Jesus' resurrection from the dead. This is, at least, the meaning which the majority of Christian churches give to this feast. But alternative memories of Easter also exist. The Masowe Enyenyedzi Church, a fast-expanding religious movement based in Zimbabwe, attributes to the Easter celebration a meaning radically different from that of the other Christian churches. Founded in 1931 by Shonhiwa Masedza, a cobbler from Gandanzare (eastern Zimbabwe) who called himself John the Baptist and claimed to be sent to save Africa, the movement had an anti-colonial character from the outset. The name of the current leader, Sandas Nhamoyebonde, also called Nyenyedzi, is used to designate the church, which is said to number six million followers. They understand Easter in a particular way. According to their beliefs, Jesus Christ was sent by God to deliver people of the white race, whilst Masedza,

49 Bishop Antonius Markos, An Introduction into Theology of Mission, 2nd ed. (Johannesburg: Coptic Bishopric of African Affairs, 2001), 133-134. In an interview with Victor Molobi, Bishop Markos shared his belief that Mark was born in Libya. See Victor Molobi, 'Celebrating the martyrdom of John Mark: A conversation with Bishop Antonius Markos of the Coptic Church.' Unpublished paper read at the Church History of Society of Southern Africa conference held in Potchefstroom, 13-15 August 2015.

50 Ibid, 133. 
his successors Mudyiwa and Nhamoyebonde, the third leader, were sent by God to deliver Africans. ${ }^{51}$

The Masowe Enyenyedzi Church is not the only religious movement which underplays the role of Jesus in salvation. The Church of Jesus Christ on Earth by His special envoy Simon Kimbangu, founded by Simon Kimbangu in the Belgian Congo, professes that Kimbangu is the Holy Spirit in association with this two sons. In South Africa the Nazareth Baptist Church, founded by Isaiah Shembe in 1910, without completely eliminating Jesus Christ, tends to replace him by Shembe, the emphasis being laid on the Father and the Holy Spirit in the Trinity. The difference between these two religious movements and the Masowe Enyenyedzi Church is that the latter subverts the meaning of Easter by reconfiguring it as a memorial of the founder's resurrection. The memory of Christ, the Risen Lord, is turned into an empty shell.

\section{CHRISTIAN TOPONYMY AS A LIEU DE MÉMOIRE}

To conclude this overview of memory practices in southern African Christianity, we shall make a brief incursion into toponymy, the branch of lexicography which studies place names. ${ }^{52}$ Toponyms mark both the landscape and the imagination. Giving a name to a river, an estuary, a town or a mountain is like planting a tree. Name-givers hope to shape the memories of the future generations. As we shall see, Christian toponyms are not uncommon in South Africa. They attest to the role of travellers, conquerors, missionaries and city planners in the modelling of a Christian consciousness in the country.

The name of one province - Natal (Christmas in Portuguese), later changed into KwaZulu-Natal - and of several bays, islands and estuaries - St-Helena Bay (Western Cape), St Sebastian Bay (Western Cape), Cape St-Francis (Eastern Cape), St Lucia (KwaZulu-Natal) - are remnants from the passages of Portuguese ships en route to India via the island of Mozambique. One place name - St Croix Island (Eastern Cape) - has a French origin, presumably because it was given by travellers from France.

51 Philip Musoni, 'Contestation of "the holy place." A critical analysis of the Masowe Enyenyedzi Church's religious shrines in the Zimbabwean religious landscape.' Unpublished paper read at the bi-annual conference of the Society for the Study of Christian Spirituality (SSCS), Johannesburg, 20-24 May 2015; Musoni, 'Easter celebrations: A critical study of Masowe Enyenyedzi Church's approach to the event.' Unpublished paper read at the Church History of Society of Southern Africa conference held in Potchefstroom, 13-15 August 2015.

52 I owe this idea to Paul Gundani who presented a paper on 'Remembering and celebrating "heroes of the Faith": Interrogating naming practices and traditions in Zimbabwean society' at the conference of the Church History of Society of Southern Africa held in Potchefstroom on 13-15 August 2015. Most of the information provided in this section is borrowed from Peter Raper's Dictionary of Southern African Place Names (Johannesburg: Lowry Publishers, 1987). 
The abundance of toponyms of biblical origin shows the pervasiveness of the Christian faith among first-generation settlers. Some refer to place names in the Old Testament - Bochum, corrupt form of Bochim (Limpopo), Dal Josaphat (Western Cape); Elim (Western Cape and Limpopo), Hermon (Western Cape), Pniel (Western Cape) and Saron (Western Cape) - or in the New Testament - Berea (KwaZulu-Natal and Gauteng), Bethlehem (Free State), Enon (Eastern Cape), Dalmanutha (Mpumalanga), Bethany (Limpopo) and Pella (Northern Cape). Others refer to biblical figures - Benoni (Gauteng), Mamre (Western Cape), Solomondale (Limpopo) and Mariannhill (KwaZulu-Natal) - or concepts - Salem (Eastern Cape), Shiloh (Eastern Cape) or Zoar (Western Cape).

Three South African localities commemorate Protestant figures. Calvinia (Northern Cape) received this name in 1851 on the proposal of a local Dutch Reformed Church minister. Coligny (North West) was named after Gaspar de Coligny, a victim of the St Bartholomew Massacre, in 1923. Wartburg (KwaZulu-Natal), the centre of a farming area with a strong German Lutheran component, was named after the castle in Saxony where Martin Luther translated the Bible into German. Only one town - Colenso (KwaZulu-Natal) - was named after a South African church leader, John William Colenso, the first Anglican bishop of Natal.

\section{CONCLUSION}

In their discussion of war memory and commemoration, Ashplant and his colleagues distinguish between three types of narratives of articulation of memory: dominant, sectional and oppositional. ${ }^{53}$ Dominant narratives of articulation of memoryare produced and propagated by state-sponsored institutions. In a Christian context, this role is played by authorised church structures. Examples of this form of memory transmission are the canonisations of African saints, which only the Holy See can officialise, the 2010 Edinburgh Conference, in which the mainline churches and the World Council of Churches played a major part, and the upcoming 500th anniversary of the Reformation.

Sectional narratives of articulation of memory are produced by groups of people who share common memories and make concerted efforts to celebrate them. This is the case, for instance, of the students and staff of Umphumulo Theological Seminary who endeavoured to restore Maqhamusela Khanyile's memory in the Lutheran Church and the black members of the Seventh-day Adventist Church who decided to commemorate Richard Moko, the first indigenous pastor of their church.

Oppositional narratives of articulation of memory are characterised by the intention of challenging a dominant view of the past. But because situations change, in church as in society, memories which were oppositional at one point can become dominant or vice versa. We have seen several examples of this phenomenon. When

53 Ashplant et al., Politics of War Memory and Commemoration, 2000, 16-32. 
the French Huguenots arrived at the Cape in the late seventeenth century, the memories they shared of their resistance to King Louis XIV's religious policy were oppositional. Three hundred years later, the Huguenots, having been assimilated into the Afrikaner population in the meantime, the tercentenary anniversary of their arrival in the country was celebrated, with state funds, by the apartheid government. Today the memories of the Huguenots are only celebrated by their descendants and a few Afrikaners interested in their history. The narrative of articulation of these memories has become sectional. The opposite happened with the memories of Beyers Naudé and Albert Geyser who were marginal under apartheid. Today they contribute to the grand narrative of the struggle against apartheid to which the South African state powerfully contributes with the support of the Christian churches. By contrast the memories of the apostle Mark, said to be born in Africa and to have founded the church of Alexandria, are restricted to the relatively small circle of Coptic Christians. They challenge the dominant version of a Christian church born in the eastern and northern parts of the Mediterranean world.

This paper also showed that, when they commemorate past events and figures, the Christian churches utilise a variety of lieux de mémoire: liturgies, canonisations and beatifications, anniversary celebrations, monuments, dedicated lectures, toponyms. All these forms of commemorations are there for a purpose. Through a reference to the past, they create meaning for the present.

\section{LIST OF REFERENCES}

Ashplant, T.G., Dawson, G. and Roper, M. (eds). 2000. The politics of war memory and commemoration. London and New York: Routledge.

Christensen, K.H. 2012. 'Remembering the new martyrs and confessors of Russia.' In Rethinking the space for religion: New actors in central and southeast Europe on religion, authenticity and belonging, C. Raudvere, K. Stala and T.S. Willert (eds). Lund: Nordic Academic Press, 193-234.

Coertzen, P. 1988. The Huguenots of South Africa, 1688-1988. Cape Town: Tafelberg, 152.

Cooks, J.B. 1986. 'Richard Moko: First indigenous minister of our church in South Africa.' South African Union Lantern, 10 October 1986.

Deloos, P. 1996. Sociologie et canonisations. The Hague: Martinus Nijhoff.

Denis, P. 2003. 'The Cape Huguenots and their legacy in apartheid South Africa.' In Memory and identity: The Huguenots in France and the Atlantic Diaspora, B. van Ruymbeke and R. Sparks (eds). Charlestown: University of South Carolina Press, 286-291.

Denis, P. 2010. 'Seminary networks and Black Consciousness in South Africa in the 1970s.' South African Historical Journal 62: 174.

Denis, P. and Dlamini, P. 2015. 'Multiple layers of memory: The history of Mpophomeni told and retold.' Alternation 22(2): 76.

Denis, P. and Marschall, S. 2015. 'Editorial - Memory Studies.' Alternation 22(2): 1-7. 
Dreyer, W. 2015. 'Albert Geyser: Anti-apartheid activist as portrayed by the media.' Unpublished paper read at the Church History of Society of Southern Africa conference held in Potchefstroom, 13-15 August 2015.

Elphick, R. 2012. The equality of believers: Protestant missionaries and the racial politics of South Africa. Charlottesville: University of Virginia Press, 317.

Esler, P. 2007. “"Remember my fetters”: Memorialisation of Paul's imprisonment.' In Explaining Christian origins and early Judaism: Contributions from cognitive and social science, P. Luomanen, I. Pyysiäinen and R. Uro (eds). Leiden: Brill, 231-259.

Fiedler, K. 2010. 'Edinburgh 1910, Africa 2010 and the Evangelicals.' Studia Historiae Ecclesiasticae 36(2): 53-71.

Gundani, P. 2015. 'Remembering and celebrating "heroes of the Faith": Interrogating naming practices and traditions in Zimbabwean society.' Unpublished paper presented at the conference of the Church History of Society of Southern Africa held in Potchefstroom on 13-15 August 2015.

Halbwachs, M. 1950. The collective memory. New-York: Harper \& Row.

Hamilton, C. 2002. "'Living by Fluidity": Oral histories, material custodies and the politics of archiving.' In C. Hamilton, V. Harris et al, Reconfiguring the archive. Cape Town: David Philip, 209-228.

Hart, D.J. and Jeremy, D.J. (eds). 2013. Brands plucked from the burning: Essays on Methodist memorialisation and remembering. Evesham: Wesley Historical Society.

'List of saints from Africa', n.d. <https://en.wikipedia.org/wiki/List_of_saints_from_Africa> (accessed 13 September 2015).

Mafani, H. 2011. From Genesis to germination: Richard Moko and other African pioneers of Seventh Day Adventism in the Cape. No place, 159.

Mapala, C. 2015. 'A critical reflection on the commemoration of the Edinburgh 1910 International Missionary Conference from a Malawian perspective.' Unpublished paper read at the Church History of Society of Southern Africa conference held in Potchefstroom, 13-15 August 2015.

Markos, A. 2001. An introduction into theology of mission, 2nd ed. Johannesburg: Coptic Bishopric of African Affairs, 133-134.

Marschall, S. 2010. Landscape of memory: Commemorative monuments, memorials and public statuary in post-apartheid South Africa. Leiden: Brill, 279-281.

Maurizio, A. 2009. "Not in a Christian church": Westminster Abbey and the memorialisation of Byron.' The Byron Journal 37(2): 41-50.

Metz, J.P. 2007. Faith in history and society: Toward a practical fundamental theology. New York: Crossroads Publishing Company, 87-96.

Molobi, V. 2015. 'Celebrating the martyrdom of John Mark: A conversation with Bishop Antonius Markos of the Coptic Church.' Unpublished paper read at the Church History of Society of Southern Africa conference held in Potchefstroom, 13-15 August 2015.

Musoni, P. 2015a. 'Contestation of "the holy place." A critical analysis of the Masowe Enyenyedzi Church's religious shrines in the Zimbabwean religious landscape.' Unpublished paper read at the bi-annual conference of the Society for the Study of Christian Spirituality (SSCS), Johannesburg, 20-24 May 2015. 
Musoni, P. 2015b. 'Easter celebrations: A critical study of Masowe Enyenyedzi Church's approach to the event.' Unpublished paper read at the Church History of Society of Southern Africa conference held in Potchefstroom, 13-15 August 2015.

Nash, D. 2013. Christian ideals in British culture: Stories of belief in the twentieth century. London: Palgrave MacMillan, 101-117.

Nhalpo, M.C. to Mafani, H. 19 May 2010. 'Hobbes' Place: An exploration of Adventist history and culture.' <https: hobbes.wordpress.com/2006/10/30/Richard-moko> (accessed 13 September 2015).

Nichol, F.D. 1976. Seventh-day Adventist Encyclopedia, Vol. 10. Washington: Review and Herald Publishing Association.

Nora, P. (ed.). 1984-1992. Les Lieux de mémoire, 3 Vol. Paris: Gallimard, translated as Realms of memory: The construction of the French past, 3 Vol. 1996-1998. New York: Columbia University Press.

Nürnberger, M. 2001. 'Maqhamusela Khanyile's life and testimony.' Natalia 31: 34-52.

Radstone, S. 2008. 'Memory studies: For and against.' Memory Studies 1(1): 31-39.

Radstone, S. and Schwarz, B. (eds). 2010. Memory: Histories, theories, debates. New York: Fordham University Press, 3.

Raper, P. 1987. Dictionary of Southern African place names. Johannesburg: Lowry Publishers.

Ricoeur, P. 2004. Memory, history, forgetting, translated by K. Blamey and D. Pellauer.

Rousselet, K. 2011. 'L'Église orthodoxe russe et la mémorialisation des répressions à la période soviétique : de la victime au héros.' In Commémorer les victimes en Europe: XVIe-XXIe siècles, F.X. Nérard andt D.E. Kenz. Paris: Champ Vallon, 183-196.

Sokupa, M. 2012. 'Law and religious freedom in South Africa: Challenges facing the Seventh-day Adventist Church.' International Journal for Religious Freedom 4: 111-113, reproduced in Nederduitse Gereformeerde Theologiese Tydskrif, 54 Supplement 4, 2013, 146-148.

Sokupa, M. 2015. 'Celebrating the memory of Richard Moko: A Seventh-day Adventist heritage reflection.' Unpublished paper read at the Church History of Society of Southern Africa conference held in Potchefstroom, 13-15 August 2015.

Spalding, A.W. 1962. History and origins of the Seventh Day Adventists. Washington: Review and Herald Publishing Association, Vol. 4, 22.

Stanley, B. 2009. The World Missionary Conference Edinburgh 1910. Grand Rapids: Eerdmans Publishing, 12.

Tangaard, K. 14 October 2009. 'The strange story of a black missionary. Sedition? Or plain bloody blind-mindedness?' $<$ http://www.eastlondon-labyrinth.com/townships/moko.jsp> (accessed 13 September 2015).

Tankard, K. 1985. East London: The creation and development of a frontier community. MA Thesis, Rhodes University.

Tessler, M. and Nelson, K. 1994. 'Making memories: The influence of joint encoding on later recall by young children.' Consciousness and Cognition 3, 321. In Recording oral history: A guide for the humanities and social sciences, 2005, 36, 2nd edition, V. Yow. Oxford: Altamira Press. 
'The Beyers Naudé Centre of Public Theology' < http://academic.sun.ac.za/tsv/centres/ beyers naude_sentrum $>$ (accessed 14 September 2015).

Todorov, T. 2001. 'The uses and abuses of memory.' In What happens to history: The renewal of ethics in contemporary thought, H. Machitello (ed.). New York: Routledge, 11-22.

Van Aarde, A., De Villiers, P. and Buitendag, J. 2014. 'The forgotten struggle of Albert Geyser against racism and apartheid.' HTS Teologiese Studies/Theological Studies 70(1): art. 2820, 10.

Vosloo, R. 2011. 'The Dutch Reformed Church: Beyers Naudé and the ghost of Cottesloe.' Studia Historiae Ecclesiasticae 37(1): 1-17.

White, L. 2000. 'Telling more: Lies, secrets, and history.' History and Theory 39, December, 1122.

Winters, J. 1995. Sites of memory, sites of mourning: The Great War in European culture history. Cambridge: Cambridge University Press.

Wood, J. 2015. 'Persecution, past and present: Memorialising martyrdom in late antique and early medieval Córdoba.' Al-Masāq: Journal of the Medieval Mediterranean 27(1): 41-60. 